\title{
APRESENTAÇÃO DO DOSSIÊ: PSICOLINGUÍSTICA
}

O primeiro número do volume 7 da Revista Letrônica apresenta um leque de trabalhos que demonstram a identidade diversificada e jovem da área da Psicolinguística. Diversificada pela amplitude de interesses de pesquisa, jovem pela ainda gama de perguntas a serem respondidas. Há investigações do processamento e da percepção dos diversos níveis da língua: fonológico, morfológico, sintático e semânticolexical. Além disso, são contemplados processos cognitivos complexos, a saber, compreensão, produção de resumos, revisão textual e fluência verbal. Apesar de ainda incipiente, a Psicolinguística apresenta-se diversa e interessada em desvendar os processos cognitivos que subjazem a aquisição e a compreensão; acreditamos que esta edição da Letrônica reflete este aspecto investigativo e diverso da área.

Para o leitor em busca de instrumentos, os trabalhos que compõem este número utilizam-se de diversos métodos de pesquisa para buscar respostas às suas perguntas e, desta forma, de variados instrumentos de pesquisa: há estudos de leitura automonitorada, priming, julgamento de aceitabilidade; há instrumentos como questionários, testes de compreensão oral e escrita e de produção, técnica de escuta preferencial, tarefas de fluência verbal e tarefas de memorização de sentenças. Há, ainda, uma latente relação entre o processamento e a compreensão da linguagem e a cognição nos trabalhos, evidenciada pela investigação de diferentes aspectos de ambos: memória de trabalho, memória semântica, memória de curto prazo, funções executivas e atenção. Desta forma, para o leitor que ainda engatinha nos estudos da área, um leque de informações e pontos de partida; para o leitor da área, outro leque para aprofundar suas futuras investigações e diálogos.

Os 15 artigos aprovados sempre por dois pareceristas ad hoc e/ou pelos membros do conselho editorial da revista foram distribuídos em quatro grandes grupos. 
O primeiro grupo é composto por artigos sobre a Aquisição da Linguagem. Nesse grupo, há dois estudos sobre momentos e populações diferentes em processos de aquisição e que se utilizam de modalidades diferentes de compreensão: (1) a aquisição de pistas prosódicas por bebês brasileiros (Silva e Name) e (2) as hipóteses do processo de aquisição da categoria aspectual por crianças surdas com e sem implante coclear (Silva).

O segundo grupo consiste em um conjunto de artigos que abordam o tema geral Bilinguismo e L2. Esses artigos estão relacionados (3) à organização e representação mental do léxico de bilíngues (Toassi e Mota); (4) ao comportamento de bilíngues proficientes em relação à construção resultativa gramatical (Oliveira); (5) à memorização de sentenças por bilíngues derivadas dos pressupostos da Hipótese da Regeneração e à acessibilidade de representações sintáticas (Souza); (6) a diferenças individuais na capacidade de memória de trabalho de aprendizes de inglês como L2 e o desempenho em tarefas de compreensão oral (Fay e Buchweitz) e (7) a estratégias utilizadas por estudantes brasileiros de nível universitário ao produzir resumos escritos de um texto expositivo em inglês (Bailer, Winfield, Almeida e Roscioli).

No terceiro grupo, há artigos sobre o tema geral texto. Os tópicos abordados estão relacionados (8) à compreensão de textos narrativos por crianças em fase de alfabetização (Barboza e Pereira); (9) a aspectos psicolinguísticos da compreensão de textos e suas implicações pedagógicas (Wolff e Lopes); (10) ao processamento da coesão e da coerência textual em português brasileiro, com foco nos correferentes (Simões e Leitão) e (11) à revisão textual, considerando a detecção de inadequações linguísticas por revisores novatos e expertos (Leite e Magalhães).

Sintaxe e semântica compõem o último grupo de artigos. Os dois primeiros artigos contemplam o processamento sintático (12) das estruturas recursivas linguísticas e aritméticas (Marcilese, Corrêa e Augusto) e (13) da anáfora, considerando a Teoria da Ligação, de Chomsky (Oliveira, Ferrari Neto e Castor). Os outros dois artigos abordam aspectos semânticos: (14) estruturas e processos necessários para modelar a construção de sentido de espaço e de movimento (Duque) e (15) a fluência verbal semântica de adultos após acidente vascular cerebral no hemisfério direito, de acordo um uma perspectiva neuropsicolinguística (Becker, Müller, Rodrigues, Villavicencio e Salles). 
Por fim, esperamos que a seleção de artigos deste número da Revista Letrônica demonstre a abrangência de assuntos, abordagens e métodos da Psicolinguística e consiga instigar o leitor novato ou experiente na área a aprofundar seus estudos e achar novos colaboradores para dialogar. Boa leitura!

Os organizadores:

Professor responsável Augusto Buchweitz (PUCRS)

Doutorandos Bernardo Kolling Limberger (PUCRS) e Rossana Kramer (PUCRS) 